\title{
学童に於ける鼻・副鼻腔症状の動向
}

一春秋の相違一

河原田 和 夫

\section{Nasal Symptomes in Children}

- Seasonal Difference in Spring and Autumn-

\author{
Kazuo Kawarada
}

(Nagano Red Cross Hospital)

\begin{abstract}
An annual survey has conducted nasal symptomes in school children ranging in age from 6-15 years twice a year in spring and autumn for the past 6 years. In children aged 69 years, the nasal symptomes appear more often in spring than autumn, while in those age 12-15 years they occurred more often in autumn than in spring.
\end{abstract}

Key words: nasal symptom, sinusitis, children

\section{はじめに}

学童生徒の健康診断は, 学校保健法の定めに より，内（小児）科医，眼科医，耳鼻科医，お よび歯科医により，毎年 6 月 30 日まで実施しな ければならないとされている。しかし，学校医 の充足されない地域もあることから，眼科や耳 鼻科については, 内科医が代診したり, 大学あ るいは病院勤務医に健康診断のみ依頼すること がある。

著者は, 信州大学医学部勤務中に, ある山村 小中学校の定期健康診断に参加する機会があっ た. 同地域では, 春の定期健康診断のみならず, 秋10月にも同様の健康診断を行っているが， 6 年間連続して参加しえた経験の一部をまとめて みた。

春秋 2 回の健康診断実施が，どのような効用 をもたらしたかについては，別に論ずるとして，
本報では，鼻・副鼻腔症状が，春秋でちがいが あるかどらか検討した。なお要旨の一部はすで に述べている1）ので，春秋 2 回の健康診断に関 する包括的内容もふくめ再述したい.

\section{対象および方法}

対象は, 長野県上水内郡小川村立中学校生徒 92 人（1977年 4 月同校入学, 1980年 3 月同校卒 業）である．春秋の健康診断の際，「鼻がつま る, 鼻汁がでやすい」「くしゃみがでやすい」 の症状の有無掞よび鼻・副鼻腔炎の有無につい て調査した。

小川村小中学生の全般的な傾向を知るために 1976年の春の健康診断以降, 全員に同様の調査 をしているが，本報においては，その一部を予 備調査とした.

また同村の環境について気象観測, 河川の水 質検査などを検討したが, 春秋の差はみられない。 


\section{結果}

\section{1 ）予備調査}

小川村小中学校生徒全員を対象としたが，小 学校の 2,3 年については, 資料上欠除があり 対象から除外した。したがって小学 1 年74人, 同 4 年 74 人, 同 5 年 78 人, 同 6 年 93 人, 中学校 全学年 258 人, 合計 577 人が, 予備調査の対象と した.

「鼻がつまる，鼻汁がでやすい」「くしゃみ がでやすい」の症状の有無を春秋とにわけ，4 分画とし，百分率で示したものが表 1 である.

これらを実数であらわし，春の数を分母とした 比較を示すと次の様になる。

○鼻がつまる，鼻汁がでやすい

$\begin{array}{cccc}\text { 小 } 1 & \text { 春 } 13 \text { 人 } & \text { 秋 } 9 \text { 人 } & 0.7 \\ \text { 小 } 4 & \text { 春 } 9 \text { 人 } & \text { 秋 } 13 \text { 人 } & 1.4 \\ \text { 小 } 5 & \text { 春 } 7 \text { 人 } & \text { 秋 } 18 \text { 人 } & 2.6 \\ \text { 小 } 6 & \text { 春 } 17 \text { 人 } & \text { 秋 } 22 \text { 人 } & 1.3 \\ \text { 中 } & \text { 春 } 28 \text { 人 } & \text { 秋 } 46 \text { 人 } & 1.6 \\ \text { ○くしゃみがでやすい } & \end{array}$

表 1 予備調査集計
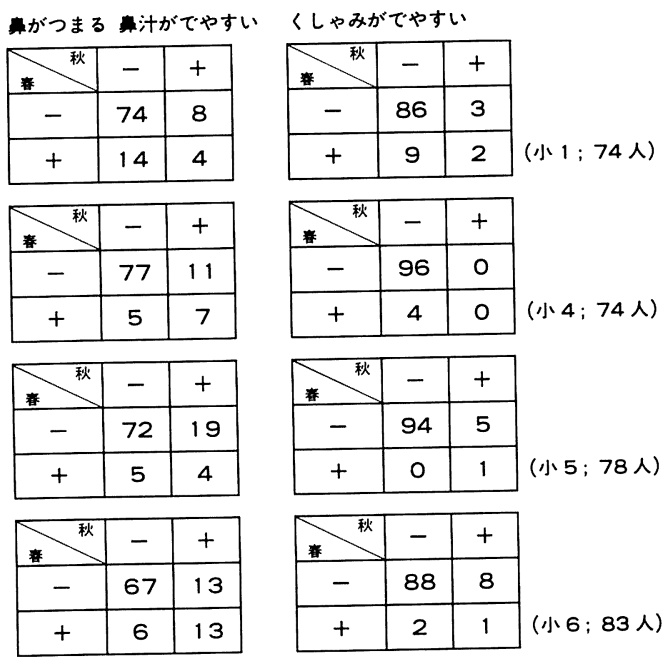

\begin{tabular}{|c|c|c|}
\hline N $^{\text {秋 }}$ & - & + \\
\hline- & 80 & 9 \\
\hline+ & 2 & 9 \\
\hline
\end{tabular}

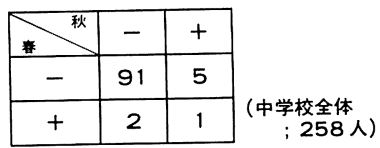

(数字は\%を示す)
小 1 春 8 人 秋 3 人 $\quad 0.4$

小 4 春 3 人 秋 0 人 -

小 5 春 1 人 秋 5 人 5.0

小 6 春 3 人 秋 8 人 2.7

中 春 8 人 秋 16 人 2.0

これらを概括すると小学校高学年, 中学生に 秋に症状のみられる傾向がある。

2 ) 本調查

1977年に中学生となった 92 人（予備調査では 小 6 に相当)について 3 年間調査を継続した (図 $1)$.

鼻・副鼻腔に関しては，8\%から $3 \%$ に減少 しつつある。

「鼻がつまる，鼻汁がでやすい」は，春 $8 \sim 14$ $\%$ ，秋15〜25\%であった． 3 年間を通じて， 1 回以上症状のみられた生徒は 32 人（35\%）で, そのらち秋のみに症状がみられたのは 9 人（28 \%）である。

「くしゃみがでやすい」については，春 2 〜 $3 \%$ であったのに対し，秋 $8 \sim 12 \%$ と，秋に多 くみられた。 3 年間を通じて， 1 回以上症状の みられた生徒は，21人（23\%）と，前者の「鼻 がつまる，鼻汁がでやすい」に比べると少なか ったが，秋のみに症状がみられるとした生徒は，

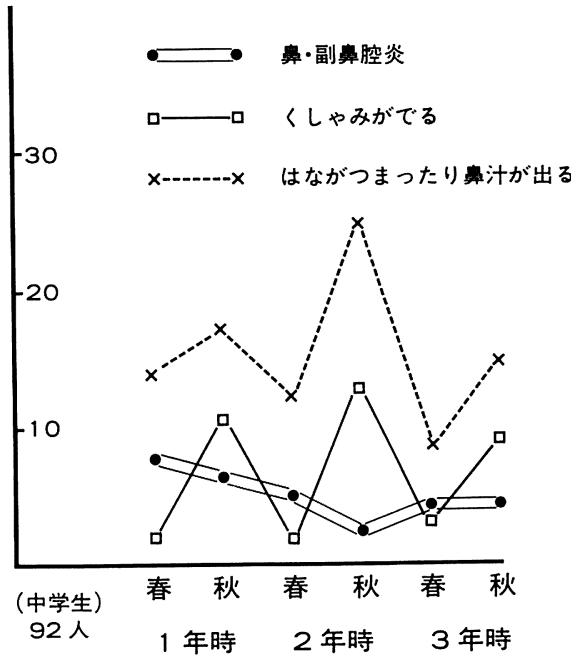

図 1 中学生各年次の動向 
14人（67\%）と多かった（図 2).

21 人についてみると 1 年の秋のみ 5 人， 2 ， 3 年の秋のみ 5 人, 毎年秋 4 人といら内容であ った（図 3 ).

「鼻がつまる，鼻汁がでやすい」と訴えた生 徒数は，「くしゃみがでやすい」と訴えた数よ り多かったが，秋のみに限ってみれば，後者に 多くみられた点が特徵的である.

\section{考察}

一般に，小児の鼻・副鼻腔炎は，成長ととも に減少するが，逆に鼻アレルギ一的症状はふえ てる2）といわれる。成長発育, 栄養, 気候条件,

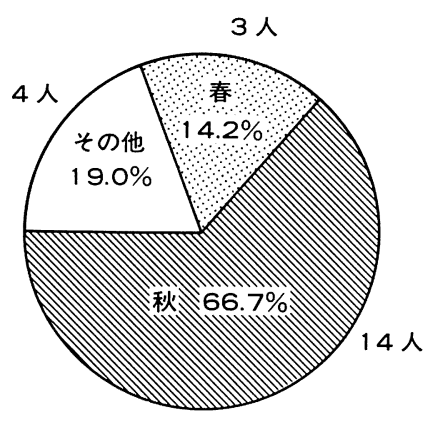

くしゃみがでる 〈中学生 21 人中〉

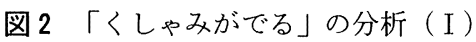

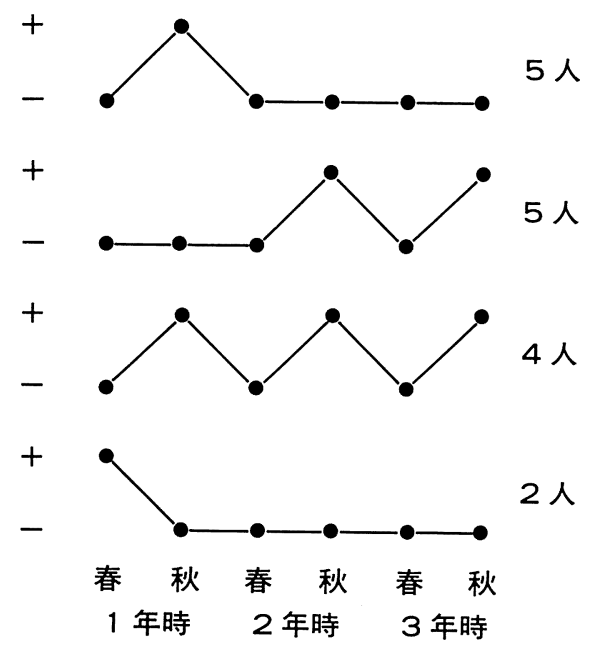

図 3 「くしゃみがでる」の分析（II）
社会環境などが，そうした因子として考えられ ている。

今回, 山村小中学校での健康診断業務を通じ て，一般的にいわれている「鼻・副鼻腔炎は減 ったが，鼻アレルギーは増えている」といらこ とが妥当なのか，そしてこれまで問題にされて いなかった春秋の季節による相違があるのかに ついて考えてみた.

鼻アレルギーの一側面を示している「くしゃ みがでやすい」について，成長するにつれ春よ り秋に多くみられるようになった点について注 目した。

まず気象条件であるが，健康診断時の気温， 降水量については, 春秋の差はみられない。し かし, 気象医学的な観点から鼻アレルギーある いは腺窩性扁桃炎の有無について論じている報 告3)もあることから，地域の気象動態を巾広く 把握しなければならない。

飲料水としている河川の水質検査を行ったが, $\mathrm{pH}$ について春8.1，秋8.6と若干の差があった. 花粉による影響を考慮して, 周辺の植物相を調 ベたが，ハンノキ，スギ，ヒノキ，マッ，ヨモ ギは共通, 中学校周辺にイネがみられた。両校 が近接していることや，通学区域が同じである ことから，この点については差異がないものと 考えた。

大気に関しては，山村であり煤煙を出す工場 がないことから，検討しておく必要がないと考 えた。

気象，大気をふくめ社会的環境の差異は，と もかくとして, 同一環境のなかで, 小学校低学 年と中学生とを比べると, 季節によるちがいが はっきりしている。このことは，成長発育の過 程で中学生時代に, 秋に鼻・副鼻腔粘膜の感受 性がたかまったと考え，小児の鼻・副鼻腔症状 については，季節による推移も考慮しなければ ならない。

$$
\text { まとめ }
$$

小児の鼻・副鼻腔炎は減少しつつあるが，鼻 ・副鼻腔症状である「鼻がつまる，鼻汁がでや 
すい」「くしゃみがでやすい」などは，しばら く続いている.

小中学生を対象に, 春秋 2 回健康診断を 6 年 間にわたり実施したところ, 鼻・副鼻腔症状に 関し, 小学校低学年児は, 秋より春に, 中学生 は, 春より秋に多くみられ, 成長発育の過程で 春と秋とが逆転することについて若干の検討を 試みた。

本報の要旨は，第95回日耳鼻長野県地方部会例会 (1980年 2 月 24 日松本市), 第 21 回鼻科学会総会 （1982年10月 9 日名古屋市）において述べた.

本報をまとめるにあたり，小川村役場，小川村小 学校, 小川村中学校, 厚主連新町病院の協力に深謝
する. 田口喜一郎教授の御校閲に深謝します。

\section{文献}

1）河原田和夫, 平林 千春, 坂口 正範: 鼻症状 の季節による变動. 医学のあゆみ $121: 945 〜$ 946, 1982.

2）名越好古 : 小児副鼻腔炎の変遷と対策. 日本鼻 科学会誌 $18: 26 \sim 31,1979$.

3) 笠井 和: 気象と疾病一発病と気象一. 小児科 MOOK 気象医学 (馬場和夫, 小林 登編). 33 ４2頁, 金原出版, 東京, 1980 .

$$
\left(\begin{array}{l}
\text { 別刷請求先 : 河原田 和夫 } \\
\text { ₹ } 390 \text { 松本市旭 } 3-1-1 \\
\text { 信州大学医学部耳鼻咽喉科学教室 }
\end{array}\right)
$$

